\title{
Research on the College Teachers' Spiritual Culture Requirement and Culture Construction in the View of Cultural Confidence*
}

\author{
Zhengfeng Chen \\ Xi'dian University \\ Xi'an, China
}

\author{
Pei Zheng \\ Xi'dian University \\ Xi'an, China
}

\begin{abstract}
In terms of current college teachers' cultural self-confidence, combined with the characteristics of college English teachers' teaching practice, this article, with teachers' spiritual culture needs as the starting point, conducts an investigation and analysis of the situation of college teachers' lack of confidence in culture and their spiritual culture needs. In order to realize the self-worth and promote the happiness of college teachers, many strategies are put forward to reconstruct teachers' spiritual culture needs and culture construction in many fields, such as establishing a new concept of teaching and educating people, strengthening the construction of teachers' morality, improving the culture of college teachers and enriching their spiritual culture activities.
\end{abstract}

Keywords-cultural confidence; spiritual culture; culture construction of college teachers

\section{INTRODUCTION}

Currently, multiplicity, diversification and variability have become the characteristics of China's culture environment. Besides, with the unprecedented economic and social changes, and the various interacting ethos, ideology confusion and mental anxiety are prominent. In this period, the cultural hegemony implicit in globalization and the crisis of faith that emerged in social transformation have made China more and more open and frequent in the international communications of economy, culture and education. With the rapid spread of globalization, each culture must accept the challenge of exotic culture in today's multicultural conflicts. In this process, as far as Chinese culture is concerned, many Chinese, especially young people, have felt an "identity crisis" because of this challenge. Faced with the new situations, in 2016 July when the general assembly marking the 95th anniversary of the funding of Chinese Communist Party was held, General Secretary Xi Jinping put forward in his important speech: "We must foster stronger

*[Fund Project] Shaanxi Education Science Program (SGH17H050) in 2017: The Research on the Construction of O2O College English Teaching Model in the Post- MOOC Era; Xi'an Social Science Fund Project

(17Y27) in 2017: Cultural Confidence Studies of College English Teaching in Xi'an under the Background of Internationalization ; Key funding projects for special funds for basic scientific research in central colleges (RW170403) in 2017 and (RW170116) in 2017; .Research Topic of Xi'dian Union Work in 2017:The Study of the Spiritual and Cultural Needs of the Faculty from the Point of Cultural Self-confidence. confidence in the path, theory, system and culture of socialism with Chinese characteristics." In the speech, General Secretary combines cultural self-confidence with road self-confidence, theoretical self-confidence and institutional self-confidence, clarifying that cultural selfconfidence becomes the "fourth self-confidence" of socialism with Chinese characteristics after "three selfconfidence."

Meanwhile, at the 19th National Congress, General Secretary $\mathrm{Xi}$ incisively pointed out that whether to confirm the cultural confidence is a critical issue concerning the nation's fortune, the cultural security and the independence of the national spirit. This shows that in the construction of the spiritual culture, we must strengthen cultural confidence, promote the prosperity of socialist culture, foster and practice the core values of socialism, strengthen ideological and moral construction, prosper and develop socialist literature and art, and promote the development of cultural undertakings and cultural industries. Therefore, we must thoroughly study and propagate the 19th CPC National Congress's spirit, strengthen the "four self-confidence". And we should use the Xi Jinping's Thought on Socialism with Chinese Characteristics for a New Era to arm our minds, guide our practice and promote our work. Cultural confidence, as pointed out by $\mathrm{Xi}$ Jinping, is a more basic, broader and deeper self-confidence. The practice of roads, theories and institutions will slowly be internalized as cultural genes. Cultural confidence is a deeper national character. As a result, in this new era, it is particularly important for the development of Chinese society and we should attach importance to cultural confidence.

\section{The MEANing AND SignificANCE OF CUlturaL CONFIDENCE}

By "cultural confidence" is meant that a country, a nation and a political party fully affirm its own national cultural value and firmly believe in its cultural vitality. Cultural confidence, a hierarchical and multidimensional system, contains two levels, consciousness and behavior. It is a positive awareness of the national culture and a positive and unrelenting activity in promoting the national culture. By "cultural confidence of a university" is meat that a college fully affirms its cultural value and firmly believes in its own 
cultural vitality. Cultural self-confidence is extremely important for the national awareness and the cultural identity and sense of belonging to the Chinese nation. In other words, it represents that a country and a nation highly appreciate its own cultural implications and values, and firmly believe in its cultural vitality. In the great course of building a well-off society in an all-round way, a university plays a great role that no other organization can replace and compete. The root cause lies in the cultural confidence that a university holds. As the foundation of spiritual and cultural construction, cultural self-confidence has its foundation and universality. Cultural self-confidence not only affirms the process of cultural development of a university, but also inherits and develops Chinese excellent traditional culture. In fact, cultural self-confidence means that a nation, a country and a party firmly believe in their own cultural concept, thus generating the recognition and affirmation of their own cultural values and their firm belief in their own cultural vitality. Therefore, it is imperative for university teachers to insist on cultural self-confidence and establish a correct view.

\section{INVESTIGATION AND RESEARCH ON COLLEGE TEACHERS' SPIRITUAL AND CULTURAL NEEDS}

This study, with the action research method and survey research method employed, includes questionnaires and interviews with teachers and students. From September 2017 to November 2017, this study last for two months. In this study, 350 teachers of different colleges and majors from Xi'an University of Electronic Science and Technology, Northwest University and Xi'an Jiaotong University were selected as research subjects. Through the investigations and analysis of the status of their spiritual culture and cultural self-confidence (Two questionnaires), this study shows status and problems of the spiritual and cultural needs of university teachers. A total of 400 questionnaires were administered, 350 returned and 350 valid. Overall, there are 350 valid samples of this survey, with an effective rate of $87.5 \%$. Also, teachers and students are investigated and analyzed in the forms of interviews as shown in "Table I".

TABle I. Questionnaire Analysis of College Teachers' SPIRItual Culture (SC) Needs

\begin{tabular}{|c|c|c|c|c|c|}
\hline Attitudes towards SC Needs & $\begin{array}{l}\text { Strongly } \\
\text { Agree }\end{array}$ & Agree & Not Sure & Disagree & $\begin{array}{l}\text { Strongly } \\
\text { Disagree }\end{array}$ \\
\hline $\begin{array}{l}\text { Cultural Self-confidence of Teachers is } \\
\text { important }\end{array}$ & $90 \%$ & $8 \%$ & $1.2 \%$ & $0.3 \%$ & $0.5 \%$ \\
\hline $\begin{array}{l}\text { Be more Interested in the Manifestation of SC } \\
\text { than Its Content and Value }\end{array}$ & $30.1 \%$ & $43.7 \%$ & $1.4 \%$ & $7.1 \%$ & $8.7 \%$ \\
\hline $\begin{array}{l}\text { The quality of SC activities has a great influence } \\
\text { on my teaching }\end{array}$ & $97.1 \%$ & $1 \%$ & $0.2 \%$ & $0.7 \%$ & $1 \%$ \\
\hline SC activities for teachers should be more diverse & $80.3 \%$ & $9.2 \%$ & $1.5 \%$ & $7.3 \%$ & $1.7 \%$ \\
\hline Democratic right of teachers is very important & $97.3 \%$ & $0.2 \%$ & $0 \%$ & $2.7 \%$ & $0 \%$ \\
\hline $\begin{array}{l}\text { Participating in foreign cultural exchange is vital } \\
\text { for teachers' cultural construction }\end{array}$ & $93 \%$ & $3.1 \%$ & 1. $2 \%$ & $0.3 \%$ & $2.2 \%$ \\
\hline $\begin{array}{l}\text { The environment of society and campus has a } \\
\text { great influence on teachers' cultural construction }\end{array}$ & $93 \%$ & $3.1 \%$ & 1. $2 \%$ & $0.3 \%$ & $2.2 \%$ \\
\hline
\end{tabular}

As can be seen from the figure, $90 \%$ of teachers believe that cultural self-confidence is very important while there are some teachers lacking cultural self-confidence. Compared with $43.7 \%$ of teachers who don't think the forms of culture is important, $30.1 \%$ of teachers are more interested in the forms of culture than its content and value. And there are as many as $97.1 \%$ of teachers hold a view that the quality of activities of Chinese spiritual culture exerts a great influence on teaching, which proves the significance of the spiritual culture's connotation and essence. $80.3 \%$ of teachers believe that the activities of spiritual culture should be enriched. $97.3 \%$ of teachers think exercising their democratic rights is very important to themselves. $93 \%$ of teachers think it is very important to participate in cultural exchanges with foreign workers and that the environment of society and campus can affect their spiritual and cultural construction to a large extent.

According to the interviews with teachers, the vast majority of teachers put their scientific research and works in a vital place. Therefore, lack of enthusiasm for participating in the activities of spiritual culture, they have no time to care about the extracurricular activities organized by the schools. At present, job burnout of college teachers in some universities is quite serious. In some schools and departments, cultural construction is relatively simple and they also have no enough cultural self-confidence. So it is imperative to figure out how to broaden the cultural horizon of college teachers, correctly handle the relationship between teaching and living, enhance teachers' sense of happiness, 
and establish cultural self-confidence. This shows that for most teachers the cultural and spiritual self-confidence and cultural activities in colleges and universities need to be further strengthened. And it is of utmost urgency to step up spiritual culture construction, meet the demands of university teachers for it and improve the spiritual outlook of them.

\section{THE RECONSTRUCTION STRATEGIES OF COLLEGE TEACHERS' NeEDS OF SPIRITUAL CULTURE}

\section{A. Establish a New Concept of Teaching and Educating People, and Explore and Practice Modern University Spirit with a High Degree of Cultural Awareness and Self-confidence}

Contemporary Chinese universities shoulder the function of cultural inheritance and innovation and assume the important task of lead the excellent Chinese traditional culture into the world. Under the background of implementing the "One Belt and Road" Initiative and speeding up the building of a world-class university and a first-rate university, it is imperative to build a university culture with Chinese characteristics and establish socialist university spirit with Chinese characteristics which combines national traditions and brand of times together. In university, a talent-intensive place, the communication between teachers' and students' thoughts contributes to the cultivation of creative thinking. Students are active in thinking, rich in imagination and full of curiosity. What's more, various fashions will rise form universities and then spread to the society. From this perspective, the construction of college teachers' spiritual culture plays a critical leading role. Therefore, we must study and understand the spirit of General Secretary's speech. We should profoundly grasp the rich connotation of cultural self-confidence. It is necessary to fully understand that upholding cultural self-confidence is of great significance to the rise and fall of the fortunes of the country, to cultural security and to the independence of the national spirit.

Moreover, cultural influence is a formidable and lasting force. As teachers in colleges and universities, it is necessary to fully deepen the concept of educating people based on the principle of "educating people oriented, moral education first, ability being top priority and all-round development". They should also enhance the reforms of educating, teaching and the personnel training mode and improve the quality of personnel training. University's cultural resources should be made full use of to inherit culture and actively promote cultural development, which further enhances cultural selfconfidence. Teachers should do their utmost to achieve a high degree of cultural confidence and cultural selfimprovement. And not only that, as college teachers, they should make clear the mission of cultural self-confidence, use the core values of socialism with Chinese characteristics to guide the construction of college students' values and strive to help students to observe the objective world with the stand and viewpoint of Marxism. Teachers should help students improve the ability to analyze and solve problems and distinguish right and wrong. Exploring and practicing the spirit of modern universities should also be focused on so as to enrich the spiritual and cultural construction of both teachers and students, and create a good mental outlook.

\section{B. Constantly Strengthen the Construction of Teachers' Morality, Ideological and Moral Education and Academic Ethics, and Constantly Improve the Ethics Standards}

Colleges are built to strengthen moral education and cultivate people. Colleges should improve the norms of teachers' conduct, professional ethics and assessment methods. At the same time, other duties are to set the standard of teachers' ethics evaluation, advocate the advanced model of ethics construction, and strive to build an excellent teaching style of "lofty ideals, patriotic dedication, professionalism rigorous study and advancing with times". Colleges should also advocate the work style of "dedication, responsibility, diligent and pragmatic" to guide the majority of teachers to better educate people and enhance their ethics. Therefore, it is necessary to run colleges in the direction of socialism with Chinese characteristics, to follow the laws of education and teaching and to strengthen the education of teachers' ideological, moral and academic virtues, which further develops good moral standards. Only in this way can college teachers develop a perseverance heart to do well in educating and teaching people and creating innovative literature achievement. Only in this way can they assume the sacred mission of teaching with a firm cultural confidence and dare to take on their share of responsibility of promoting national talent construction with their best efforts. In order to the competence of students, those college teachers whose majors are related to this issue should reinforce their own work, influence students with their own academic and professional knowledge and better convey the deeper thoughts of educating people through various means to each classmate. Only in this way can they deliver positive energy to students and become a leader of spiritual culture and a teacher with good moral regulations.

\section{Comprehensively Enhance the Humanistic Quality of College Teachers, and Actively Learn all Kinds of Advanced Cultural Elements from Society}

When engaged in teaching work, teachers should actively learn various advanced cultural elements from society to improve the spiritual culture construction. Not only should college teachers explore and practice modern university spirit, but also they should condense the essence of various cultures with a high degree of cultural awareness and confidence. That means teachers should actively learn from the outstanding cultural achievements of universities at home and abroad, accept the muti-cultural integration and stress the innovation in the whole course of cultural construction to promote the sustainable development of school culture. This not only requires colleges and universities to increase the content of excellent traditional culture courses, but also to carry out various forms of cultural exchanges between Chinese and foreign teachers and students in various forms to broaden teachers' spiritual vision. It is necessary to establish excellent culture exchange and sharing mechanism oriented to international top universities. Meanwhile, 
colleges should also increase the introduction, training and support of talents, strengthen the construction of teaching staff in literary and arts disciplines, and strive to create a team with a correct cultural outlook and wisdom, which dares to take its responsibility and innovate. There are other aspects that should be done to enhance the humanities accomplishment of teachers and students and adapt themselves to the new era. For example, colleges should stimulate the enthusiasm of teachers and students, and encourage them to make achievements in areas such as cultural confidence and innovation.

\section{Make Us of New Media Technology to Lead Teacher Culture Construction and Organize Healthy and Harmony Campus Cultural Activities}

College teachers can take advantage of contemporary new media such as the Internet, Wibo, Wechat and QQ to create a new platform with new characteristics for cultural construction. They should also hold a series of quality cultural activities and focus on the development of the cultural connotation of universities. In colleges, whether it can promote the all-round development of teachers and students and meet the needs of university construction should be set as the radical standard to measure the quality of cultural construction. Colleges should conduct extensive publicity and muti-angle and systematic communication to enhance colleges' influence in society, organize cultural and cultural activities and improve universities' popularity and soft power, so as to achieve the functions of promoting culture, such as leading and educating people. Besides, campus cultural activities that both teachers and students can participate in should be organized normally and an excellent cultural exchange and sharing mechanism oriented to the top universities in the world should be established. Specifically, in colleges and universities, it is possible to organize campus cultural brand activities with university characteristics, such as cultural celebrities' speech, high art exhibition, campus cultural festival and campus singing contest. Other excellent cultural activities that reflect the values pursued by teachers and students can be also held. They should strive to build an excellent cultural activity system which is in line with the actual needs of teachers and students and combines thoughts and artistry together. Of course, it is okay for colleges to invite cultural figures and academic masters to hold highlevel lectures and reports. Top-level literary and artistic groups are also a good choice. Teachers should be required to take part in these activities so as to improve their culture level. What's more, colleges can conduct various sinoforeign exchange programs for teachers. As a result, teachers' self-worth can be achieved and their sense of happiness can be improved.

\section{CONCLUSION}

The University undertakes the mission of inheriting outstanding culture, innovating the ideology and culture, and promoting the dissemination and exchange of culture. It is of far-reaching significance to construct the spiritual culture of teachers in colleges and universities. Under the international background of economic globalization and multicultural conflicts, building a good campus culture and meeting the spiritual and cultural needs of and the culture construction of college teachers are important for colleges to play their educational functions of personnel training and cultural inheritance and innovation and to promote the colleges' sustainable development. Above all, it is useful to study the cultural construction of college teachers from the perspective of cultural self-confidence. Not only can it contribute to the realization of the leadership of college culture, but it is also of great theoretical significance to promote the recognition of socialist core value system and build a culturally strong socialist country. It also provides a new research paradigm for the heritage of traditional Chinese culture and the theory and practice of cultural innovation.

\section{REFERENCES}

[1] Du Z.J. Culture Inferiority, Culture Conceit and Culture Selfconfidence[J]. Morals and Civilization, 2011(4).

[2] Fu L. A review of the century: the study of Chinese University Culture[M]. Beijing: Educational Science Publishing House, 2009.

[3] Research Center for the development of Social Science in the Ministry of Education. Review of Campus Cultural construction in University[M]. Beijing: Educational Science Publishing House, 2011.

[4] Yuan G.R. China's High-level University Construction - from 211 Project to 2011 Program[M]. Beijing: Higher Education Press, 2012. 